\title{
Studies on Variability, Heritability and Genetic Advance for Yield and Its Attributes in Brinjal (Solanum melongena L.)
}

\author{
Ashish Kumar ${ }^{1 *}$, Vipin Kumar ${ }^{1}$, Amit Kumar ${ }^{2}$, Vivak Ujjwal ${ }^{1}$ and Ramraj Sen ${ }^{3}$ \\ ${ }^{1}$ SVP University of Agriculture \& Technology, Meerut (UP), India \\ ${ }^{2}$ SMS, Hort. Krishi Vigyan Kendra, Tepla, Ambala- (Hry.), India \\ ${ }^{3}$ IARI, New CORC, Mandsor, (MP), India \\ *Corresponding author
}

\section{Keywords \\ Brinjal, Variability, \\ Heritability and genetic advance \\ Article Info \\ Accepted: \\ 12 May 2019 \\ Available Online: \\ 10 June 2019}

\begin{abstract}
A B S T R A C T
The present investigation carried out on "variability, heritability and genetic advance analysis in relation to selection of parental lines in brinjal (Solanum melongena L.)" at Horticultural Research Centre of Sardar Vallabhbhai Patel University of Agriculture and Technology, Meerut. The experimental material comprised of eight parental lines namely, K.S-331, DBL-24, A. Abhilomb, A. Parthibha, J.B.-6, F.Collection-2, J.B.L.-03-04 and Assury along with twenty eight F1crosses which were produced by the parents. These parental lines were collect from IIVR Varanasi and used for further crossing programme in half diallel crosses fashion. Parental lines were grown during Kharif 2017 and all possible cross combinations were made to produce $28 \mathrm{~F}_{1} \mathrm{~s}$. 12 different characters like Plant height $(\mathrm{cm})$, primary branches per plant, plant spread, days to first flowering, days to first fruit set, days to first fruit picking, average fruit weight, fruit length, fruit diameter, fruit index, fruits per plant and yield per plant were taken into consideration. Analysis of variance in the present investigation shows that the crosses evaluated differed significantly among all the 28 traits. The results revealed that among the all cross A. Parthibha x A. Abhilomb produced highest fruit yield, plant height, fruit weight and also took minimum days to flowering and days to fruit set. High heritability in broad sense was observed for average fruit weight, high genetic advance in percent of mean was observed for diameter of fruit followed by average fruit weight. High genotypic coefficient of variation (GCV) was recorded for diameter of fruit followed by fruit index and phenotypic coefficient of variation (PCV) for diameter of fruit followed by average fruit weight.
\end{abstract}

\section{Introduction}

Brinjal (Solanum melongena L.) belongs to the family Solanaceae and is a diploid species $(2 \mathrm{n}=24)$ is an admired vegetable crop that grown all over the world though there is a heavy concentration in Asia. It is also known as eggplant. In Uttar Pradesh the production of brinjal is around 151.9 tonnes with an area of about 4.5 hectares having productivity of 33.75 tonnes per hectares (Anon, 2017). Brinjal (Solarium melongena L.) is an important vegetable crop cultivated throughout the warmer region of the world 
and has its centre of origin as India (Bhaduri, 1951 and Thompson et al., 1957). It is an important article of diet, consumed in a great variety of ways and it has also considerable Ayurvedic medicinal properties. Thus they are highly beneficial for regulation of blood sugar levels and also help to control the absorption of glucose. The demand for its use is increasing irrespective of season. It also recommended for the remedy of liver problems (Shukla and Naik, 1993). It is grown in tropics and sub tropics.

\section{Materials and Methods}

Present investigation was carried out at Horticulture Research Centre of Sardar Vallabhbhai Patel University of Agriculture \& Technology, Meerut. Field plot was well prepared for conducting of the experimental material comprising of entries 36 (8 parents and $28 \mathrm{~F} 1 \mathrm{~s})$. The experiment was laid out in randomized block design with three replications. The row to row and plant to plant spacing were maintained at $60 \mathrm{~cm} \times 45 \mathrm{~cm}$, respectively. Eight genotypes were collected from IIVR, Varanasi. All the recommended practices were applied prior to transplanting and after transplanting to raise a good crop.

Five competitive plants were marked in each plot per replication and observations were recorded on these plants for 12 quantitative and quality characters viz., Plant height $(\mathrm{cm})$, Primary branches per plant, Plant spread, Days to first flowering, Days to first fruit set, Days to first fruit picking, Average fruit weight, Fruit length, Fruit diameter, Fruit index, Fruits per plant and Yield per plant. The analysis of variance for different characters was carried out in order to assess the genetic variability among genotypes as given by Cochran and Cox (1950). The level of significance was tested at $5 \%$ and $1 \%$ using $\mathrm{F}$ table values given by Fisher and Yates (1963). Both phenotypic and genotypic co- efficient of variability for all characters were estimated using the formula of Burton and De Vane (1953). The broad sense heritability (h2) was computed for all the characters as the ratio of genotype at variance to the total variance as suggested by Hanson et al., (1956) and the values were expressed in percentage and interpreted as per the method of Robinson et al., (1949).

\section{Results and Discussion}

The analysis of variance revealed the significant differences among the genotypes for all the traits (Table 1). Highly significant differences were recorded among the varieties for all the characters suggesting that the genotypes included in the experiment were having appropriate variation for genetic analysis. The characters showing high degree of variation have more scope for their further improvement (Mohanty, 2002). The relative variability of different characters is presented in (Table 2). The phenotypic and genotypic coefficient of variance was calculated for all the 12 characters (Table 3 ) and observed that phenotypic coefficient of variance was in general higher than the genotypic coefficient of variance for all the characters indicating that under studied are influenced to various degrees by the environmental factors.

The cross of A. Parthibha x A. Abhilomb showed highest plant height $(105.40 \mathrm{~cm})$, early days to flowering (35.87), days to fruit set (37.67), days to first fruit picking (43.93), average fruit weight (196.12 gm) and highest fruit yield per plant (2542.58). Highest number of primary branches (12.87) were observed in cross of A. Abhilomb x DBL-24. Highest plant spread (110.62) was found in F.Collection-2 x A. Parthibha. Length of fruit was found maximum (18.92) in J.B.-6 x K.S.331. Highest diameter of fruit (12.58) and fruit index (160.39) was found in F.Collection-2 x A. Abhilomb. 
Table.1 Analysis of variance for 12 traits involving parents and F1s in brinjal (Solanum melongena L.)

\begin{tabular}{|c|c|c|c|c|c|c|c|c|c|c|c|c|c|}
\hline $\begin{array}{c}\text { Sourced } \\
\text { of } \\
\text { variation }\end{array}$ & $\begin{array}{l}\text { d. } \\
\text { f. }\end{array}$ & $\begin{array}{l}\text { Plant } \\
\text { height }\end{array}$ & $\begin{array}{l}\text { Primary } \\
\text { branches } \\
\text { per plant }\end{array}$ & $\begin{array}{l}\text { Plant } \\
\text { spread }\end{array}$ & $\begin{array}{c}\text { Days to } \\
\text { first } \\
\text { flowering }\end{array}$ & $\begin{array}{l}\text { Days to } \\
\text { first fruit } \\
\text { set }\end{array}$ & $\begin{array}{l}\text { Days to } \\
\text { first fruit } \\
\text { picking }\end{array}$ & $\begin{array}{l}\text { Average per } \\
\text { fruit weight }\end{array}$ & $\begin{array}{c}\text { Length of } \\
\text { fruit }\end{array}$ & $\begin{array}{c}\text { Diameter } \\
\text { of fruit }\end{array}$ & $\begin{array}{l}\text { Fruit } \\
\text { index }\end{array}$ & $\begin{array}{l}\text { Number } \\
\text { of fruit } \\
\text { per plant }\end{array}$ & $\begin{array}{l}\text { Yield of } \\
\text { fruit /plant }\end{array}$ \\
\hline $\begin{array}{l}\text { Repli- } \\
\text { cation }\end{array}$ & 2 & 181.23 & 12.60 & 426.01 & 15.66 & 17.49 & 28.49 & 6010.63 & 21.97 & 31.72 & 3803.57 & 73.35 & 275440.0 \\
\hline Parents & 7 & $520.39 * *$ & $8.32 * *$ & $443.84 * *$ & $66.09 * *$ & $69.89 * *$ & $80.76 * *$ & $3932.27 * *$ & $18.58 * *$ & $14.71 * *$ & $2421.26^{* *}$ & $33.82 * *$ & 239854.3** \\
\hline $\begin{array}{l}\text { F1 } \\
\text { hybrids }\end{array}$ & 27 & $1692.12 * *$ & $122.86^{* *}$ & $1885.08 * *$ & $20.16^{* *}$ & $18.40 * *$ & $37.79 * *$ & $3720.46 * *$ & $6.98 * *$ & $5.44 * *$ & $3010.59 * *$ & $14.84 * *$ & $1477540.1^{* * *}$ \\
\hline $\begin{array}{l}\text { Parents } \\
\text { v/s } \\
\text { hybrids }\end{array}$ & 1 & 0.13 & 0.04 & 0.14 & 0.05 & 0.01 & 0.65 & 0.29 & 0.06 & 0.00 & 0.62 & 0.01 & 232.1 \\
\hline Error & 70 & 0.86 & 0.36 & 0.47 & 0.48 & 0.68 & 0.55 & 1.17 & 0.41 & 0.10 & 36.50 & 0.28 & 1034.9 \\
\hline
\end{tabular}


Table.2 Mean performance for parents and hybrids for twelve characters of brinjal (Solanum melongena L.)

\begin{tabular}{|c|c|c|c|c|c|c|c|c|c|c|c|c|c|}
\hline S. No. & Parents & $\begin{array}{c}\text { Plant } \\
\text { height }\end{array}$ & $\begin{array}{l}\text { Primary } \\
\text { branches } \\
\text { per plant }\end{array}$ & $\begin{array}{c}\text { Plant } \\
\text { spread }\end{array}$ & $\begin{array}{l}\text { Days to } \\
\text { first } \\
\text { flowering }\end{array}$ & $\begin{array}{c}\text { Days to } \\
\text { first fruit } \\
\text { set }\end{array}$ & $\begin{array}{l}\text { Days to } \\
\text { first fruit } \\
\text { picking }\end{array}$ & $\begin{array}{l}\text { Average } \\
\text { fruit } \\
\text { weight }\end{array}$ & $\begin{array}{l}\text { Length } \\
\text { of fruit }\end{array}$ & $\begin{array}{l}\text { Diamete } \\
\mathbf{r} \text { of } \\
\text { fruit }\end{array}$ & Fruit index & $\begin{array}{l}\text { Number } \\
\text { of fruit } \\
\text { /plant }\end{array}$ & $\begin{array}{l}\text { Yield of } \\
\text { fruit } \\
\text { /plant }\end{array}$ \\
\hline 1 & K.S.-331 & 74.70 & 7.00 & 67.63 & 51.87 & 54.00 & 62.00 & 90.48 & 18.43 & 4.59 & 84.68 & 15.53 & 1245.87 \\
\hline 2 & DBL-24 & 79.51 & 6.20 & 77.83 & 50.27 & 52.40 & 60.27 & 60.43 & 10.07 & 3.82 & 38.51 & 17.27 & 1067.16 \\
\hline 3 & A. Abhilomb & 80.50 & 8.20 & 85.08 & 47.20 & 49.27 & 54.73 & 125.11 & 11.11 & 9.23 & 102.60 & 13.13 & 1562.96 \\
\hline 4 & A.Parthibha (C.K.) & 82.47 & 10.93 & 85.92 & 45.07 & 47.13 & 54.13 & 145.48 & 12.07 & 10.25 & 123.66 & 14.93 & 2019.07 \\
\hline 5 & J.B.-6 & 63.23 & 8.13 & 56.57 & 50.00 & 51.93 & 61.00 & 61.44 & 15.58 & 3.47 & 53.87 & 25.73 & 1447.20 \\
\hline 6 & F. Collection 2 & 84.67 & 5.00 & 81.24 & 48.53 & 50.53 & 57.80 & 190.03 & 11.93 & 11.58 & 138.35 & 9.20 & 1686.04 \\
\hline 7 & J.B.L.03-04 & 72.93 & 8.53 & 66.90 & 50.40 & 53.40 & 60.20 & 79.67 & 13.04 & 4.06 & 52.94 & 20.60 & 1419.93 \\
\hline 8 & Assury & 65.93 & 4.73 & 56.93 & 51.40 & 53.73 & 61.67 & 115.80 & 12.05 & 7.77 & 93.63 & 15.80 & 1783.30 \\
\hline 9 & DBL-24 x K.S. -331 & 101.55 & 9.07 & 84.00 & 49.50 & 51.60 & 58.67 & 82.45 & 15.14 & 4.60 & 69.55 & 17.60 & 1555.97 \\
\hline 10 & A. Abhilomb x K.S.-331 & 76.32 & 7.67 & 82.05 & 50.95 & 53.27 & 60.80 & 122.32 & 17.55 & 7.16 & 125.62 & 14.80 & 1872.55 \\
\hline 11 & A. Parthibha x K.S.-331 & 98.45 & 9.93 & 93.97 & 45.71 & 47.67 & 54.53 & 170.67 & 12.53 & 7.21 & 90.37 & 12.47 & 2085.93 \\
\hline 12 & J.B.-6 x K.S.-331 & 80.50 & 11.07 & 100.25 & 52.10 & 54.40 & 62.07 & 78.77 & 18.92 & 4.03 & 76.31 & 15.87 & 1366.71 \\
\hline 13 & F.Collection-2 x K.S.-331 & 93.41 & 8.93 & 80.39 & 43.28 & 45.47 & 51.53 & 155.92 & 12.29 & 8.46 & 103.74 & 13.00 & 2035.72 \\
\hline 14 & J.B.L.-03-04 x K.S.-331 & 95.17 & 8.33 & 75.32 & 51.81 & 54.13 & 60.80 & 88.16 & 17.90 & 5.55 & 99.24 & 17.00 & 1539.51 \\
\hline 15 & Assury x K.s.-331 & 60.44 & 7.20 & 85.51 & 46.00 & 48.87 & 55.40 & 122.23 & 17.16 & 5.50 & 94.30 & 14.53 & 1941.03 \\
\hline 16 & A. Abhilomb x DBL-24 & 85.58 & 12.87 & 72.06 & 50.73 & 52.93 & 60.00 & 115.26 & 14.05 & 6.65 & 93.26 & 17.53 & 2064.29 \\
\hline 17 & A. Parthibha x DBL-24 & 87.93 & 9.93 & 71.75 & 44.87 & 47.40 & 54.40 & 105.45 & 15.37 & 6.37 & 97.89 & 19.80 & 1951.51 \\
\hline 18 & J.B. -6 x DBL-24 & 83.24 & 9.27 & 60.70 & 49.80 & 52.40 & 59.27 & 70.41 & 10.80 & 4.06 & 43.89 & 25.33 & 1734.15 \\
\hline 19 & F.Collection-2 x DBL-24 & 77.77 & 10.20 & 75.47 & 45.87 & 47.93 & 55.00 & 123.27 & 10.55 & 7.63 & 80.40 & 14.67 & 1724.14 \\
\hline 20 & J.B.L.-03-04 x DBL-24 & 101.54 & 8.80 & 71.79 & 50.67 & 53.07 & 59.60 & 87.40 & 16.88 & 3.33 & 56.08 & 21.33 & 1866.61 \\
\hline 21 & Assury x DBL-24 & 95.40 & 9.07 & 62.05 & 54.20 & 56.93 & 64.47 & 90.40 & 11.30 & 6.30 & 70.97 & 14.87 & 1294.84 \\
\hline 22 & A. Parthibha x A. Abhilomb & 105.40 & 12.07 & 97.12 & 35.87 & 37.67 & 43.93 & 196.12 & 12.53 & 9.34 & 117.10 & 13.87 & 2542.58 \\
\hline 23 & J.B.-6 x A. Abhilomb & 70.54 & 12.47 & 88.65 & 48.07 & 50.87 & 57.33 & 92.50 & 15.70 & 8.46 & 132.83 & 17.93 & 1656.98 \\
\hline 24 & F.Collection-2 x A. Abhilomb & 103.56 & 10.80 & 93.97 & 55.00 & 57.80 & 65.27 & 163.52 & 12.75 & 12.5 & 160.39 & 12.93 & 2088.43 \\
\hline 25 & J.B.L.-03-04 x A. Abhilomb & 92.58 & 9.93 & 76.66 & 47.53 & 49.67 & 57.20 & 134.56 & 12.83 & 5.52 & 70.60 & 15.00 & 1920.49 \\
\hline 26 & Assury x A. Abhilomb & 72.49 & 7.33 & 60.87 & 51.53 & 54.13 & 60.33 & 84.21 & 11.60 & 7.16 & 83.06 & 14.00 & 1170.10 \\
\hline 27 & J.B.-6 x A. Parthibha & 70.37 & 9.33 & 90.32 & 43.33 & 45.73 & 51.93 & 129.70 & 13.34 & 7.27 & 96.96 & 14.87 & 1793.25 \\
\hline 28 & F.Collection-2 x A. Parthibha & 87.28 & 11.60 & 110.62 & 45.00 & 46.93 & 53.53 & 184.63 & 14.11 & 10.4 & 146.93 & 10.67 & 1777.35 \\
\hline 29 & J.B.L.-03-04 x A. Parthibha & 63.70 & 12.27 & 80.69 & 50.00 & 52.87 & 59.13 & 138.34 & 11.79 & 8.30 & 97.77 & 13.67 & 1659.57 \\
\hline 30 & Assury x A. Parthibha & 92.82 & 9.80 & 84.68 & 46.27 & 48.13 & 54.87 & 154.18 & 13.26 & 7.87 & 104.37 & 12.00 & 1816.86 \\
\hline 31 & F.Collection- 2 x J.B.-6 & 61.46 & 12.07 & 95.54 & 52.07 & 53.67 & 60.47 & 111.08 & 16.61 & 9.14 & 151.85 & 16.40 & 1872.49 \\
\hline 32 & J.B.L.-03-04 x J.B.-6 & 66.33 & 10.60 & 85.20 & 55.27 & 57.60 & 66.53 & 71.78 & 11.45 & 7.45 & 85.35 & 20.27 & 1573.17 \\
\hline 33 & Assury x J.B.-6 & 86.39 & 7.93 & 78.23 & 38.07 & 40.07 & 46.93 & 106.37 & 10.94 & 6.50 & 71.20 & 19.47 & 2143.79 \\
\hline 34 & J.B.L.-03-04 x F.Collection-2 & 88.31 & 11.87 & 93.74 & 48.13 & 50.07 & 58.13 & 174.27 & 12.71 & 8.27 & 105.10 & 10.87 & 1742.34 \\
\hline 35 & Assury x F.Collection-2 & 92.64 & 7.60 & 70.99 & 46.80 & 48.40 & 55.47 & 161.30 & 11.57 & 11.3 & 131.17 & 12.80 & 2026.51 \\
\hline \multirow[t]{5}{*}{36} & Assury x J.B.L.-03-04 & 89.22 & 9.40 & 82.16 & 54.07 & 55.93 & 63.87 & 119.59 & 10.42 & 10.3 & 108.09 & 14.20 & 1871.16 \\
\hline & Mean & 82.90 & 9.34 & 80.07 & 48.53 & 50.78 & 57.87 & 119.54 & 13.51 & 7.26 & 95.90 & 15.83 & 1747.76 \\
\hline & Range & 60.44 & 4.73 & 56.57 & 35.87 & 37.67 & 43.93 & 60.43 & 10.07 & 3.33 & 38.51 & 9.20 & 1067.16 \\
\hline & & 105.40 & 12.87 & 110.62 & 55.27 & $\mathbf{5 7 . 8 0}$ & 66.53 & 196.12 & 18.92 & 12.58 & 160.39 & 25.73 & 2542.58 \\
\hline & CD at $5 \%$ & 0.76 & 0.49 & 0.56 & 0.57 & 0.67 & 0.61 & 0.88 & 0.52 & 0.26 & 4.93 & 0.43 & 26.29 \\
\hline
\end{tabular}


Table.3 Estimation of phenotypic and genotypic variance, heritability, genetic advance in percent of mean for twelve characters of brinjal (Solanum melongena L.)

\begin{tabular}{|c|c|c|c|c|c|c|c|c|}
\hline \multirow{2}{*}{ Characters } & \multirow{2}{*}{ Mean } & \multicolumn{2}{|c|}{ Range } & \multirow{2}{*}{$\begin{array}{l}\text { Heritability } \\
(\%)\end{array}$} & \multirow{2}{*}{ GA } & \multirow{2}{*}{ GA as \% } & \multirow{2}{*}{ GCV $(\%)$} & \multirow{2}{*}{ PCV (\%) } \\
\hline & & Minimum & Maximum & & & & & \\
\hline Plant height & 82.90 & 60.44 & 105.40 & 99.47 & 26.13 & 31.52 & 15.34 & 15.38 \\
\hline $\begin{array}{l}\text { Primary branches per } \\
\text { plant }\end{array}$ & 9.34 & 4.73 & 12.07 & 91.71 & 3.96 & 42.40 & 21.50 & 22.45 \\
\hline Plant spread & 80.07 & 56.57 & 110.62 & 99.71 & 26.05 & 32.53 & 15.81 & 15.84 \\
\hline Days to first flowering & 48.53 & 35.87 & 55.27 & 97.41 & 8.64 & 17.81 & 8.76 & 8.87 \\
\hline Days to first fruit set & 50.78 & 37.67 & 57.80 & 96.56 & 8.84 & 17.42 & 8.60 & 8.76 \\
\hline $\begin{array}{l}\text { Days to first fruit } \\
\text { picking }\end{array}$ & 57.87 & 43.93 & 66.53 & 97.65 & 9.73 & 16.81 & 8.26 & 8.36 \\
\hline $\begin{array}{l}\text { Average per fruit } \\
\text { weight }\end{array}$ & 119.54 & 60.43 & 196.12 & 99.92 & 78.33 & 65.53 & 31.82 & 31.83 \\
\hline Length of fruit & 13.51 & 10.07 & 18.92 & 93.80 & 4.96 & 36.69 & 18.39 & 18.99 \\
\hline Diameter of fruit & 7.26 & 3.33 & 12.58 & 98.34 & 4.97 & 68.38 & 33.48 & 33.76 \\
\hline Fruit index & 95.90 & 38.51 & 160.39 & 96.07 & 60.33 & 62.90 & 31.15 & 31.78 \\
\hline Number of fruit /plant & 15.83 & 9.20 & 25.73 & 98.02 & 7.53 & 47.57 & 23.33 & 23.56 \\
\hline Yield of fruit /plant & 1747.76 & 1067.16 & 2542.58 & 98.91 & 627.34 & 35.89 & 17.52 & 17.62 \\
\hline
\end{tabular}


Cross J.B.-6 x DBL-24 was produced maximum number of fruits per plant (25.33) followed by J.B.L.-03-04 x DBL-24. All the characters showed significance difference over the control. That may be due to favourable environmental conditions and inheritance of genes in croees. Similar pattern for the range of per cent yield and yield attributing characters in brinjal was reported Maik KCK (2005) and Balaji et al., (2013).

The estimates of genotypic as well as phenotypic coefficient of variability were observed higher for most of the characters studeid. High genotypic and phenotypic variances have also been reported by Sabolu et al., (2014), Singh et al., (2014), Mohanty (2002), Prasad et al., (2004), and Chaudhary and Mohammad et al., (2015). The phenotypic coefficients of variation (PCV) were greater than their corresponding genotypic coefficients of variations (GCV) in respect of all quantitative traits indicating that the apparent variation is not only due to genotypes, but also due to influence of environment although the difference between GCV and PCV were narrow Arivalagan et al., (2013).

The characters showing high degree of variations have more scope for their further important. Heritability and genetic advance when estimated together are more useful for predicting the genetic progress in selection as high heritability coupled with high genetic advance reflect preponderance of additive gene action.

For this consideration, fruit weight which is high heritability (99.92) and high genetic advance as percent of mean (68.38) in diameter of fruit revealed preponderance of additive gene action.

The other characters showing high heritability with high GA are plant spread and plant height. High heritability estimates with high GA was also reported by Babu et al., (2008) and Sharma et al., (2000) for single fruit weight, fruits per plant and yield, Prasad et al., (2004) for fruit yield and single fruit weight. Moderate heritability accompanied by low GA were observed for day to 50 per cent flowering, days to first flowering, days to first fruit set indicating predominant role of non-additive gene action for these traits. Similar results have also been reported by Mili et al., (2014).

In conclusion it is evident that considerable genotypic variation existed among the genotypes indicating greater potentiality for their exploitation to improve yield and its components.

From the evaluation of thirty six genotypes of brinjal (Solenum melongena L.), it was observed that the cultivars A. Parthibha, A. Abhilomb, Assury and J.B.-6 could be the promising parents for future breeding programmes, as they had more than one desirable traits.

On the basis of variability, heritability and genetic advance. Studies, it was concluded that the selection of genotypes to improve fruit yield per plant under Utter Pradesh state. However, further work is warranted in this regard.

\section{References}

Anonymous FAO- Horticulture -Statistical year book India, 2017.

Arivalagan MR Bhardwaj KK Gangopadhyay Prasad TV Sarkar SK (2013) Mineral composition and their genetic variability analysis in eggplant (Solanum melongena L.) germplasm. J. Appl. Bot. and Food Quality; 86(1):99-103.

Babu SR Patil RV (2008) Characterization and evaluation of Brinjal genotypes. Madras Agric. J.; 95(1-6): 18-23.

Balaji Lokesh, Suryanarayana Reddy P Reddy RVSK Sivaraj N (2013) Variability, heritability and genetic advance studies in Brinjal (Solanum melongena L.) Electronic Journal of Plant Breeding. 4(1):1097-1100.

Bhaduri PN (1951) Inter relationship of non tuberiferious species of Solarium with 
some consideration on the origin of brinjal. Indian J Genet and PI. Breed; 11(1):75-82.

Burton GW Devane EM (1953) Estimating heritability in tall fescue (Festuca arundinaceae). From replicated clonal materials Agron. J.; 45: 78-481.

Chaudhary P Kumar S (2014) Variability, heritability and genetic advance studies in egg-plant (Solanum melongena L.). Plant Archives, 14(1): 483-486.

Cochran GW Cox MG. (1950). Experimental Designs. John Wiley and Sons, New York,

Fisher RA Yates F (1963) Statistical Tables for Biological Agricultural and Medical Research. Oliver and Boyd, London.

Hanson CH Robinson HF Comstock RE (1956) Biometrical studies of yield in segregating populatiosn of Korean lespedza. Agron J. 48(6): 268-272.

Maik KCK (2005) Genetic variability and divergence tudies in brinjal (Solanum melongena L.). MsC thesis. Univ Agric Sci, Dharwad, India.

Mili C Bora GC Das B Paul SK (2014) Studies on variability, heritability and genetic advance in Solanum melongena L. (Brinjal) genotype. Direct Res. J Agri. and food Sci. 2(11):192-194.

Mishra SV Warade SD Nayakwadi MB (2008) Genetic variability and heritability studies in brinjal (Solanum melongena L.) $J$ Maharastra Agri.Univ. 33(2): 267- 268.

Mohammad RNR Poodineh M Ghalandarzehi A Abkhoo J (2015) Variability, heritability and association analysis in eggplant (Solanum melongena L.). ARPNJ. Agri. and Bio. Sci. 10(12).
Mohanty BR AM Prusti (2002) Variability and selection parameters for economic characters in brinjal. Orissa $J$ Hort. 30(1):1-4.

Nayak BR PK Nagre (2013) Genetic variability and correlation studies in brinjal (Solanum melongena L.). IJABPT 4(4):211-215.

Prasad M Mehta N Dikshit SN Nichal SS (2004) Genetic variability, genetic advance and heritability in brinjal (Solanum melongena L.). Orissa J Hort. 32(2): 26-29.

Robinson, H. F., Comstock, R. E. and Harvey, P. H. 1949. Estimation of heritability and the degree of dominance in corn. Agron. J., 41: 353-359pp.

Sabolu S Kathiria KB Chintan RM Sushil K. (2014) Generation mean analysis of fruit quality traits in egg plant (Solanum melongena L.). AJCS 8(2): 243-250.

Sharma TVRS Swaroop K (2000) Genetic variability and heritability character association in brinjal (Solanum melongena L.) Indian J Horti. 57: 59-65.

Shukla V Naik LB Agro-techniques of solanaceous vegetables. Advances in Horticultural Vegetable Crops, Part-1. Malhotra publication house, New Delhi, 1993, 365.

Singh MK Yadav JR Singh BM (2014) Genetic variability and heritability in brinjal (Solanum melongena L.) Hort Flora Res. Spectrum. 3(1): 103-105.

Thompson CH Kally C William Vegetable Crops. Mc Grow Hill Book Co., Inc. U.S.A. 1957, 611.

\section{How to cite this article:}

Ashish Kumar, Vipin Kumar, Amit Kumar, Vivak Ujjwal and Ramraj Sen. 2019. Studies on Variability, Heritability and Genetic Advance for Yield and Its Attributes in Brinjal (Solanum melongena L.). Int.J.Curr.Microbiol.App.Sci. 8(06): 1507-1513.

doi: https://doi.org/10.20546/ijcmas.2019.806.181 